\title{
Trend and Development of E-Banking: A Study on Bangladesh.
}

\author{
Md. Mohiuddin \\ Associate Professor, Department of Management Studies, Jagannath University, Dhaka-1100, Bangladesh.
}

\begin{abstract}
Information technology is becoming an important factor in the future development of financial services industry, especially the banking industry. The banking sector is based on sharing of information, which itself heavily relies on information and communication technology (ICT) in order to acquire, analyze and deliver data to all relevant users. The ICT is crucial not only for information analysis, but also enables the banking sector to differentiate its offer from competitors and thereby make it a market leader. In this context, banking sector are obliged to continuously innovate and update their marketing strategies in order to closely meet the demands and the requirements of the individual customers. It also provides safe and confidential services which best suit customers' needs. The customer wants more flexibility without paying more, and his demands are clear: Make transactions wherever, whenever, and however he wants. Hence, the development of the concept of electronic financial services, more commonly known as E-banking. At present, private \& public banks of Bangladesh have taken various steps in E-banking. This work has been conducted from the secondary data maximally. This article has drawn present trend \& development of E-banking in Bangladesh and included conclusion \& recommendation.
\end{abstract}

Keywords: E-banking, Online-banking, Mobile banking, Electronic money.

\section{Introduction}

The term of e-banking varies amongst researches partially because electronic banking refers to several types of services through which bank customers can request information and carry out most retail banking services via computer, television or mobile phone (Daniel, 1999; Mols, 1998; Sathye, 1999). Burr (1996) describes that it as an electronic connection between bank and customer in order to prepare, manage and control financial transactions. E-banking is form of banking, where funds are transferred through an exchange of electronic signals between financial institutions, rather than the exchange of cash, checks, or other negotiable instruments. The ownership of funds and transfers of funds between financial institutions are recorded on computer systems connected by telephone lines. Customer's identification is by access code, such as a password or Personal Identification Number (PIN), instead of a signature on a check or other physical document. Ebanking involves individual and corporate clients, and includes bank transfers, payments and settlements, documentary collections and credits, corporate and household lending, card business and some others (UNCTAD, 2002).

Banking has never been more important to our society than it is today. The advance of communication and computer technology and the availability of the Internet have made it possible that one can do most banking transactions from a remote location even without stepping into a physical financial structure - that is, the emerging of e-banking (Bruene, 2002). The way Bill Gates (2008) announced that «banking is essential, banks are not». This quotation means that the traditional bank branch is going to vanish in order to be surrogated by electronic banking which continues to attract new users. The banking industry believes that by adopting new technology, the banks will be able to improve customer service level and tie their customers closer to the bank. Meanwhile, the banking industry has been also looking for new methods to expand its customer base and to counteract the aggressive marketing effort of those non-traditional banking entities (Graven, 2000). Larger banks that maintain expensive branch networks tend to have the greatest incentive to adopt e-banking services. In comparison, smaller banks have higher start up costs and tend to have a high initial technological cost in developing e-banking services (Treadwell, 2001).

Many banks quickly realized that there are a momentous number of customers like to do banking electronically. The application of e-banking has been proven as an effective way to reduce the costs of operation for the financial institutions. For instance, e-banking services will allow banks to reduce expenditures on physical structures. It is believed that the e-banking will help banks to cut costs, increase revenue, and become more convenient for customers (Halperin, 2001). Another important benefit from e-banking is a more effective information collection and management. A combination of a low percentage of customers using e-banking services on a consistent basis and a relatively low start-up cost in developing e-banking services in the banking industry will make the impact of e-banking (positive or negative) quite limited on financial institutions (Marenzi et al., 2001). On another hand, e-banking services could be highly demanded and desirable to accommodate the sudden, rapid growth that has occurred in other information-intensive industries such as travel and securities brokerage. Finally, the development of e-banking service has encouraged the adoption of a decentralized 
approach to give banks more needed flexibility to distribute Internet access to a much larger number of employees and potential customers.

- To know the concept of E-banking

\section{Objectives}

- To explore the present scenario of online banking in Bangladesh.

- To exhibit the online banking system of Different commercial Banks in Bangladesh.

- To identify major challenges of E-Banking.

- To make the necessary recommendations to solve the problems of E-Banking.

- To examine the present status of existing e-banking in Bangladesh.

\section{Methodology}

The present study is mainly based on secondary data related to E-banking. Secondary data and information have gathered from Books, Journals, research paper etc. Primary data and information also have collected through using observation and interview method.

\section{Electronic Banking}

\section{Conceptual Framework Overview Of E-Banking}

Electronic Banking or e-banking refers to the banking environment in which banking information as well as transactions moves and conducted through electronic medium. It includes any technology that that enables a bank to do business electronically. E-banking has different aspects like Internet banking, Online Banking and e-payments.

E-banking may be understood as term that covers all these ways of banking business electronically. The following illustration depicts the different form of e-banking services:

\section{Types of E-banking:}

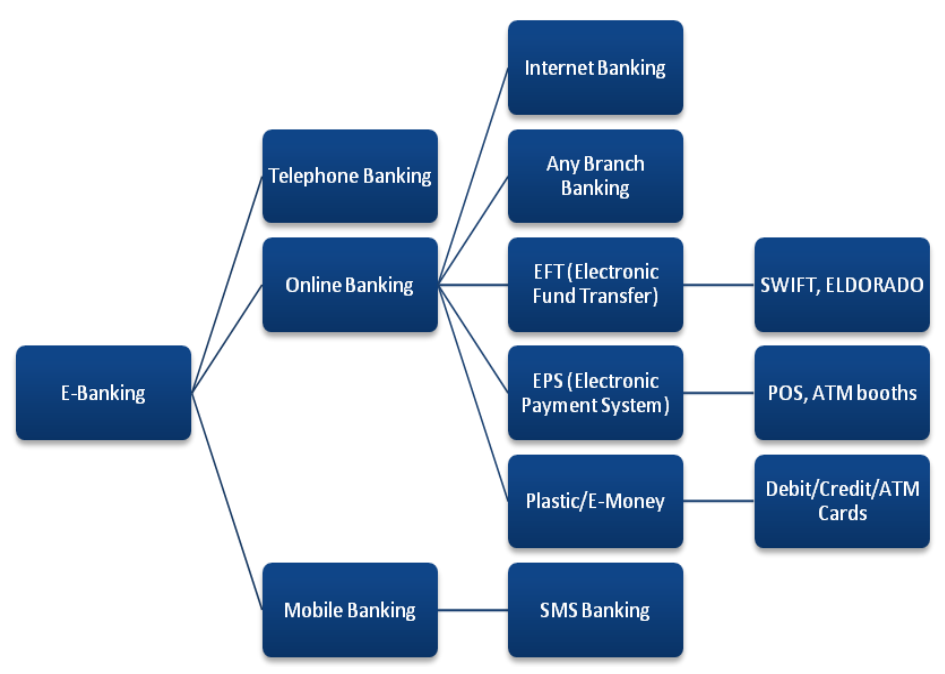

- PC Banking: The increasing awareness of the importance of literacy of computer has resulted in increasing use of personal computers through the entire world. Furthermore, incredible plummet of cost of microprocessor has accelerated the use of computer. The term 'PC banking' is used for banking business transacted from a customer's PC. Using the PC banking or home banking now customers can use their personal computers at home or at their office to access their accounts for transactions by subscribing to and dialing into the banks' Intranet proprietary software system using password.

- Internet Banking: Customers need an Internet access service to handle this type of banking. As an Internet Banking customer, he/she will be given a specific user ID and a confidential/secret or secured password so that they can access to their own account. Here customer can able to see the ledger balances, transfer his money, request something towards bank, etc.

- Virtual Banking: Virtual banks are banks without bricks; from the customer perspective, they exist entirely on the Internet, where they offer the same range of services and adhere to same rules and regulations of central banks.

- Telephone Banking: Telephone banking refers to the services provided through phone that requires the customers to dial a particular telephone number to have access to an account which provides several options 
of services. Despite huge potential, telephone banking services have not been widened enough in daily banking activities in Bangladesh. Only four banks so far provide a few options of telephone banking services such as detail account information, balance inquiry, information about products or services, ATM card activation, cheque book related service, bills payment, credit card service and so on. Funds transfer between current, savings and credit card account, stock exchange transactions etc are still inaccessible through telephone banking in Bangladesh.

- Mobile banking: Mobile banking (also known as M-banking or SMS banking) is a term used for performing balance checks, account transactions, payments etc. via a mobile device such as a mobile phone. Mobile banking is most often performed via SMS or the Mobile Internet but can also use special programs called clients downloaded to the mobile device. The standard package of activities that mobile banking covers are: mini-statements and checking of account history; alerts on account activity or passing of set thresholds; monitoring of term deposits; access to loan statements; access to card statements; mutual funds/equity statements; insurance policy management; pension plan management; status on cheque, stop payment on cheque; ordering check books; balance checking in the account; recent transactions; due date of payment (functionality for stop, change and deleting of payments); PIN provision, change of PIN and reminder over the internet; blocking of (lost/stolen) cards; domestic and international fund transfers; micropayment handling; mobile recharging; commercial payment processing; bill payment processing; peer to peer payments; withdrawal at banking agent;3 and deposit at banking agent. Despite huge prospects, only a few banks adopted mobile banking in Bangladesh during the last year.

\section{- Online Banking}

On line banking is a service provided by many banks, and Financial Institutions that allows one to conduct banking transactions over the Internet using a personal computer, mobile telephone, or handheld computer (such as a "personal digital assistant"). Through on line banking one may be able to:

* Access accounts round-the-clock, even on weekends

* See balances on line and find out whether checks or deposits have cleared

* Transfer funds between accounts

* Receive and pay bills on line(without check writing, envelopes, or stamps)

\section{Common Online Banking Services:}

Banking transactions can range from something as basic as a retail account balance inquiry to a large business-to-business funds transfer. On line banking services, like those delivered through other delivery channels, are typically classified based on the type of customer they support. The following table lists some of the common retail on line banking services offered by banks are as follows:

- Account management

- Bill payment and presentment

- New account opening

- Investment/Brokerage services

- Loan application and approval

- Business-to-business payments

\section{Required Physical Infrastructure for E-Banking}

- Internet: The Internet is a global system of interconnected computer networks that use the standard Internet Protocol Suite (TCP/IP) to serve billions of users worldwide. It is a network of networks that consists of millions of private, public, academic, business, and government networks of local to global scope that are linked by a broad array of electronic and optical networking technologies. The Internet carries a vast array of information resources and services, most notably the inter-linked hypertext documents of the World Wide Web (WWW) and the infrastructure to support electronic mail.

- Intranet: An intranet is a private computer network that uses Internet Protocol technologies to securely share any part of an organization's information or network operating system within that organization. The term is used in contrast to internet, a network between organizations, and instead refers to a network within an organization. Sometimes the term refers only to the organization's internal website, but may be a more extensive part of the organization's information technology infrastructure. It may host multiple private websites and constitute an important component and focal point of internal communication and collaboration.

- Hardware: The essential hardware required to build a complete online banking system includes: Personal Computers

Servers

Routers 
Trend and Development of E-Banking: A Study on Bangladesh.

Firewalls

Modems

POS (Point of Sale) Terminals

ATM (Automated Teller Machines) booths

Software: For conducting online banking operations several software are now available such as FLEXCUBE, a banking software which enables banks to process and store banking transaction data and making payments through a dedicated client-server network. Another type of statistical software EViews (Econometric Views) is a statistical package for Windows, used mainly for time-series oriented econometric analysis. Different banks use different types of software depending on the cost and other factors.

Electronic Money (E-Money): Electronic money (also known as e-currency, e-money, electronic cash, electronic currency, digital money, digital cash or digital currency) refers to money or scrip which is only exchanged electronically. Typically, this involves the use of computer networks, the internet and digital stored value systems. Electronic Funds Transfer (EFT) and direct deposit are all examples of electronic money. Also, it is a collective term for financial cryptography and technologies enabling it.

Plastic Money: Plastic money is a plastic card issued by banks or financial institutions with a magnetic stripe or chip that holds machine readable identification code (account number, customer's personal identification number, and other such information readable by ATMs). Bank cards are used for electronic commerce (with magnetic stripe readers or via Internet) and for banking transactions through Automated Teller Machines (ATMs). Types of plastic money include:

$>$ Credit Cards: Credit Card can be called as an equivalent of a loan sanctioned by the bank to its customers. Credit card facilitates and makes it possible to "Use First and Pay Later" the specified amount of credit as per the agreed terms of sanction. This card facilitates the cardholder to purchase goods and services from the merchant establishments and shops through the collaborating credit card companies like VISA, MasterCard, Maestro, and Cirrus.

> Debit Cards: A Debit Card provides for online electronic payment like Credit Card but from savings or current accounts of the cardholder for purchases. This card is a deposit access product where cardholder uses his own money in his bank account through the debit card on the principle of "Pay First and Use Later". Debit card contains the symbol or hologram of collaborating company such as VISA, MasterCard, Maestro and Cirrus etc.

> ATM Cards: ATM Card can be used to withdraw money, deposit money, balance enquires, deposit bills in the account. The cardholder must maintain a savings bank account or current account with the bank. On issuance of card, the cardholder is intimated a four digit secret Personal Identification Number (PIN). The cardholder is always required to maintain safely the PIN to prevent fraudulent activity.

ATM Card-cum-Debit Card: ATM Card-cum-Debit Card can be used both as an ATM card and Debit card as a method of payment when purchasing goods and services in Bangladesh and Overseas. The cardholder is responsible for all transaction made by the use of the card. In Bangladesh most of the debit cards issued by banks are also ATM cards. For example, Dhaka Bank Limited, DBBL, SCB, HSBC, BRAC Bank and other banks operating in Bangladesh provides ATM Card-cum-Debit Card.

$>$ Smart Card: The smart card is an amazing piece of technology. It is the size of a regular ATM card but is capable of storing over a 1000 times more data. The data can be encrypted and hence the card is completely temper-proof. The card can also be personalized to the holder by printing personal and other details on the card face.

$>$ Point of Sales: Point of sale (POS) or checkout is the location where a transaction occurs. A "checkout" refers to a POS terminal or more generally to the hardware and software used for checkouts, the equivalent of an electronic cash register. A POS terminal manages the selling process by a salesperson accessible interface. The same system allows the creation and printing of the voucher.

$>$ Electronic Funds Transfer: Electronic funds transfer or EFT refers to the computer-based systems used to perform financial transactions electronically. An EFT is the electronic exchange or transfer of money from one account to another, either within the same financial institution or across multiple institutions.

$>$ Electronic Payment System: Electronic payment is an integral part of electronic commerce. Broadly de-fined, electronic payment is a financial exchange that takes place online between buyers and sellers. The content of this exchange is usually some form of digital financial instrument (such as encrypted credit card numbers, electronic checks, or digital cash) that is backed by a bank or an intermediary, or by legal tender. 
Trend and Development of E-Banking: A Study on Bangladesh.

\section{Mobile banking}

Mobile banking was a term used for performing balance checks, account transactions, payments etc. via a mobile device such as a mobile phone. The standard package of activated that mobile banking covers are: mini-statements and checking of account history; alerts on account activity or passing of set thresholds; monitoring of term deposits; access to loan statements; access to card statements; mutual funds/equity statements; insurance policy management; pension plan management; status on cheque, stop payment on cheque; ordering check books; balance checking in the account; recent transactions; due date of payment; PIN provision, change of PIN and reminder over the internet; blocking of (lost/stolen) cards; domestic and international fund transfers; micro-payment handling; mobile recharging; commercial payment processing; bill payment processing; peer to peer payments; withdrawal at banking agent; and deposit at banking agent. Despite huge prospects, only a few banks adopted mobile banking in Bangladesh during the last year.

\section{Tele-banking}

Tele-banking service was provided by phone. To access an account it was required to dial particular telephone number and there were several options of services. Tele banking services widened not enough in daily banking activities in Bangladesh. Only four banks so far provided a few options of tele banking services such as detail account information, balance inquiry, information about products or services, ATM card activation, cheque book related service, bills payment, credit card service and so on. Funds transfer between current, savings and credit card account, stock exchange transactions etc.

\section{Present Scenario Of E-Banking In Bangladesh}

The commercial banking system dominates Bangladesh's financial sector. Bangladesh Bank is the Central Bank of Bangladesh and the chief regulatory authority in the sector. The banking sector of Bangladesh comprises four categories of scheduled banks. These are four state-owned commercial banks (SCBs), five stateowned development finance institutions (DFIs), thirty private commercial banks (PCBs) and nine foreign commercial banks (FCBs). The number of banks remained unchanged at 48 in 2008. These banks had a total number of 6886 branches as of December 2008. The number of bank branches increased from 6717 to 6886 owing mainly to opening of new branches by the PCBs during the year.

Online Banking in Bangladesh is yet to develop according to international standard. At present, several private commercial banks (PCBs) and foreign commercial banks (FCBs) offer limited services of telephone banking, internet banking, and online banking facilities working within the branches of individual bank in a closed network environment. As a part of stepping towards e-banking, the FCBs have played the pioneering role with adoption of modern technology in retail banking during the early 1990s whereas the state-owned commercial banks (SCBs) and PCBs came forward with such services in a limited scale during the late 1990s.

\section{Supported Infrastructure}

All types of Electronic Banking operations require a well-established ICT infrastructure throughout the country. Online Banking largely depends on the country's overall ICT infrastructure, legal environment and skilled human resources. At present the infrastructure for Online Banking is not satisfactory because of high cost and low penetration rate. This is one of the reasons for which the entire banking sector is still out of online system.

There is also lack of technically skilled human resources. Computer and Internet is still out of reach of general people of the country. The following statistics will provide a detailed synopsis of the overall situation of the supported infrastructure for implementing Online Banking.

The infrastructure of a country is very important for implementing online banking. For online banking major cost is to setup backbone network. Fortunately Bangladesh Railway has a high-speed optical fiber network parallel to the railway path owned by Bangladesh Railway. Its total capacity is about 2.5 gigabits per second. This fiber optic network covers almost every important parts of the country. Bangladesh has been connected with the information superhighway on the $20^{\text {th }}$ May, 2006. It is a landmark of ICT sector of Bangladesh. The cable network covering some 786 miles across the country from the Bay of Bengal will provide a fiber-optic link with a data transfer capacity of 10 gigabits per second compared to the 150 megabits per second bandwidth now used by the state owned BTTB and dozens of private Internet Providers.

After connecting with the information superhighway, the total country will be connected by fiber optic backbone; certainly it will be a milestone for infrastructure of implementing online banking in Bangladesh. In Bangladesh most of the banking hardware are available. The hardware available for online banking is entirely procured from foreign origins with a local distributor. Online banking operation hardware includes; servers, workstation, printers, scanner ATM, POS terminals, etc and networking hardware includes switch, Router, VSAT connectivity etc. The software support for internet banking, i.e. FLEXCUBE is available in Bangladesh. Again Bangladesh Government is working on the copyright law and the preservation of intellectual property act. 
Trend and Development of E-Banking: A Study on Bangladesh.

After the successful implementation of all these policies and strategies we are expecting that more than $50 \%$ of the banks will be offering internet banking facilities which is now $12 \%$ only.

\section{Status of Computerization of Banking System in Urban and rural areas} categories:

The banking system of our country, depending on computerization can be classified into three

(i.) Completely computerized

(ii.) Partially computerized

(iii) Not computerized.

Standard Chartered Bank Ltd., City Bank NA, American Express Bank, HSBC, Dhaka Bank Limited etc. are completely computerized banks in our country. All private and state owned banks are partially computerized and not computerized. The overall picture of computerization in the banking sector of our country is presented in the following table.

Table-1 Computerized Branches in different types of Commercial Banks

\begin{tabular}{|c|c|c|c|}
\hline \multirow[t]{2}{*}{ Branches with various facilities } & \multicolumn{3}{|c|}{ Availability in Banks } \\
\hline & NCBs & $\mathrm{PCBs}$ & FCBs \\
\hline Computerized Branches & $19 \%$ & $38 \%$ & $100 \%$ \\
\hline Number of Branches Linked within branches & $3 \%$ & $1 \%$ & $76 \%$ \\
\hline
\end{tabular}

The overall computer density in the banking sector is 1.64. For foreign commercial banks (FCBs) the computer density is 45.34 , where as for NCBs the ratio is only 0.41 . The specialized bank scenario is almost same as the NCBs, 0.43. On the other hand, private commercial banks have comparatively higher ratio, 4.94. As a whole 81.81 percent banks do not have any local area network (LAN), 30 percent have WAN (Wide Area Network) but for some banks many branches are outside of WAN connectivity. At present, all the foreign banks in our country are using online banking system. They are the pioneer of implementing online banking systems in Bangladesh, but now most of the private banks of our country are using online banking systems.

Table 2: Computerization of Bank Branches by Categories, 2003-2011

Table 2 provide the overall picture of computerization in the banking system of Bangladesh during 2003-2011. In 2003, out of 5,860 branches (NCBs 3,619; SBs 1,173; PCBs 1,056; and FCBs 13), only 539 branches (NCBs

\begin{tabular}{|c|c|c|c|c|c|c|c|c|c|}
\hline & $\mathbf{2 0 0 3}$ & $\mathbf{2 0 0 4}$ & $\mathbf{2 0 0 5}$ & $\mathbf{2 0 0 6}$ & $\mathbf{2 0 0 7}$ & $\mathbf{2 0 0 8}$ & $\mathbf{2 0 0 9}$ & $\mathbf{2 0 1 0}$ & $\mathbf{2 0 1 1}$ \\
\hline NCBs & 2.65 & 4.14 & 7.02 & 8.35 & 10.09 & 11.89 & 14.43 & 16.12 & 16.38 \\
\hline SBs & 1.96 & 2.04 & 2.18 & 2.06 & 4.20 & 4.20 & 4.39 & 4.35 & 4.38 \\
\hline PCBs & 38.54 & 46.32 & 67.67 & 85.86 & 95.67 & 97.76 & 98.45 & 98.90 & 98.99 \\
\hline FCBs & 100.00 & 100.00 & 100.00 & 100.00 & 100.00 & 100.00 & 100.00 & 100.00 & 100.00 \\
\hline Total & 9.20 & 11.74 & 18.95 & 23.91 & 28.61 & 31.10 & 33.50 & 35.42 & 36.95 \\
\hline
\end{tabular}

SBs 23; PCBs 407; and FCBs 13) were computerized, and only two FCBs were providing any branch banking facility connecting a total of six branches under their respective on line network. By the end of 2010, a significant improvement in computerization can be observed especially by the PCBs. Out of 6,565 branches (NCBs 3,388; SBs 1,347; PCBs 1,776; and FCBs 54) in 2006, a total of 2,426 branches (NCBs 555; SBs 59; PCBs 1,758; and FCBs 54) were computerized of which 651 branches of 22 PCBs, and 7 FCBs were providing any branch banking facility under respective bank online network.

Figure 1 : ATM Booths and POS Terminals in the Banking System, 2003-2011

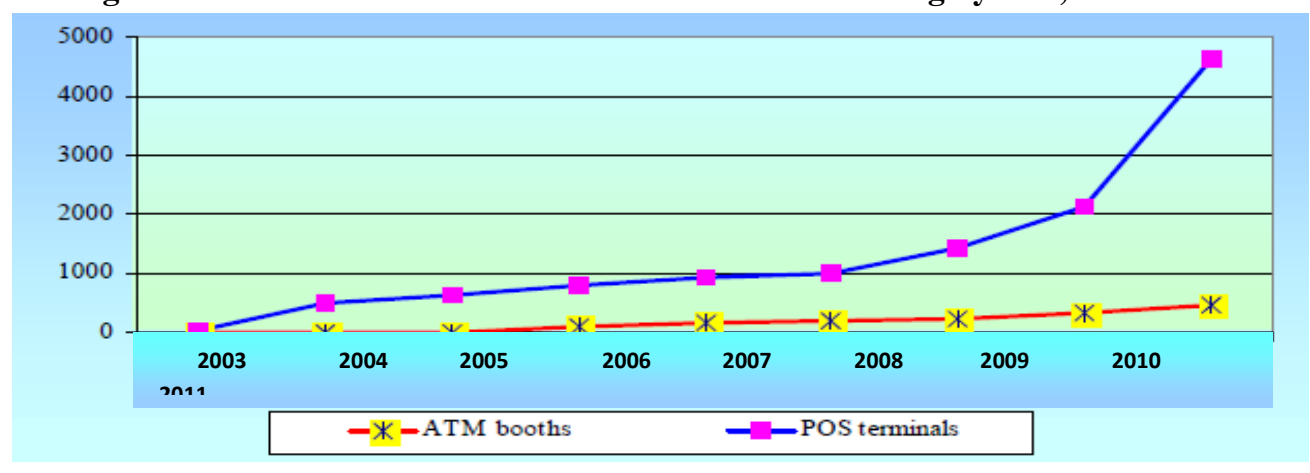


One FCB introduced ATM and POS services for the first time in Bangladesh in 1992 and 1997 respectively. By the end of 2003, the bank has set up more than twenty ATM booths and 50 POS terminals in different locations of Dhaka city. Other categories of banks, such as PCBs, NCBs, and one SB gradually adopted both the services as a part of market competition in offering better customer services. Figure 2 shows that growth rate in adoption of POS terminals was higher compared with ATM booths during the 2003-2011 period. By the end of 2011, the number of ATM booths and POS terminals stood at 1200 and 45000 respectively covering important merchant outlets in six divisional cities and some other important district

Table-3: Position of Online Banking in Bangladesh (As on May 31, 2009).

\begin{tabular}{|c|l|c|c|}
\hline $\begin{array}{l}\text { Serial } \\
\text { No. }\end{array}$ & Various Forms of Online Banking Services & $\begin{array}{c}\text { Number of Banks } \\
\text { having online } \\
\text { banking service }\end{array}$ & $\begin{array}{c}\text { Percentage (\%) } \\
\text { (Sample size 40) }\end{array}$ \\
\hline 1. & ATM & 30 & 0.75 \\
\hline 2. & SMS Banking & 19 & 0.475 \\
\hline 3. & Electronic Fund Transfer (EFT) & 22 & 0.55 \\
\hline 4. & Virtual Banking & 7 & 0.175 \\
\hline 5. & Internet Banking and WAP & 21 & 0.525 \\
\hline 6. & Any Branch Banking & 35 & 0.875 \\
\hline 7. & Telephone Banking & 21 & 0.525 \\
\hline 8. & Point Of Sales (POS) Service & 21 & 0.875 \\
\hline 9. & SWIFT Channel & 40 & 1.00 \\
\hline 10. & Remittance (Electronic Way) & 31 & 0.775 \\
\hline 11. & Call Center & 7 & \\
\hline
\end{tabular}

Presently, the number of debit card and credit card holders were growing moderately during 2003-2011 period except for the period of 2005 and 2006 when the number of debit card holders gave a big jump and stood at 585,465 by the end of 2006. Besides, the number of credit card holders is recorded approximately 7,89,250 as of end December 2010.The total volume of transactions through ATM is recorded at BDT 0.70 billion during 1999, growing moderately up to 2001, and recording a transaction of BDT 2.11 billion at the end December 2001. Since 2001, a significant increase in transactions through ATM is observed showing a transaction volume of BDT 37.19 billion by the end of 2006. Besides, using the POS terminals, the customers made payments of BDT 0.02 billion during 1999 against their purchase of goods and services which increased to BDT 5.58 billion by the end of 2006 .

\section{Bangladesh Automated Clearing House (BACH)}

The Bangladesh Automated Clearing House (BACH) will be available from November 1, 2010 as per Bangladesh Bank announcement $\mathrm{BACH}$ is a network that enables customers, companies and other establishments (i.e. banks) to complete cheque processing within the participating banks through the BACH. Through BACH clients of banks will get their cheques cleared within one working day and machine-readable cheques, that is, MICR (Magnetic Ink Character Recognition) cheques will be in place by the time. The traditional cheques take at least three days to be cleared. This payment system will make use of the automated clearing house to enable electronic payments or fund transfers in future, and small and big business houses will be benefited.

\section{Present Status of Electronic Payment System in Bangladesh}

At present several utility service providers along with many banks have started using electronic payment system in Bangladesh. But the system has still not reached the mass majority of people in the country. Bangladesh Bank has posted an "ICT Guideline" in their web site for the banks and financial institutes to create their own ICT Policy for the security of the online transactions. Nationalized banks like Sonali, Janata, Agrani and private banks like DBBL, Eastern Bank, Standard Chartered, and HSBC etc are using ATMs and POS for payment of utility bills electronically. It is seen that Ready Cash card, Q-Cash card ATMs and POS are the mostly used options for the electronic payment. One of the problems for this is that these services are mostly available in big cities and towns. The people living in remote villages still have no idea that such a service is available. Also the card holder has to be a client of service providing bank to use the ATMs. Other options available also include Online Banking which is done by some banks through which the utility bill can be paid over Internet. But this service is yet to be started by other banks. Bangladesh Bank has already started a project on Automatic Clearing House under which the online banking will be implemented in the future.

\section{Cutting Edge EFT Technologies: SWIFT and ELDORADO}

Electronic Fund Transfer (EFT) has made transferring funds easier and faster. In traditional banking it took days to process funds to be transferred from one bank to another and to process foreign transactions. With EFT funds can be transferred within minutes from one country to another. In Bangladesh the technologies like 
SWIFT and ELDORADO are present now. SWIFT is widely used in foreign transactions where funds are transferred to foreign countries for meeting export and import operations. ELDORADO is used for interbank fund transferring which was previously made by payment orders, demand drafts (DD), telephone transfers (TT) etc.

SWIFT: SWIFT is a bank owned non-profit co-operative based in Belgium servicing the financial community worldwide. It ensures secure messaging having a global reach of 6,495 Banks and Financial Institutions in 178 countries, 24 hours a day. SWIFT global network carries an average 4 million message daily and estimated average value of payment messages is USD 2 trillion. SWIFT is a highly secured messaging network enables Banks to send and receive Fund Transfer, L/C related and other free format messages to and from any banks active in the network. Having SWIFT facility, Bank will be able to serve its customers more profitable by providing L/C, Payment and other messages efficiently and with utmost security. Especially it will be of great help for our clients dealing with Imports, Exports and Remittances etc.

ELDORADO:ELDORADO is a web based Remittance Processing System for Taka payments, which will be interfaced with the Bangladesh Bank ACH (Automated Clearing House) and will run as an independent association of member Banks. In El Dorado transactions will be settled on a bi-lateral net settlement basis. The system platform will be a direct electronic substitute of present day manual instruments such as DD (Demand Draft), TT (Telegraphic Transfer ) \& MT (Mail Transfer) used under existing inter-bank agency agreements. This remittance engine will be fully compliant with all relevant central bank regulations and will automatically provide the necessary MIS directly to Bangladesh Bank for supervision and monitoring.The essence of the ELDORADO initiative is to create a standardized IT platform that will enable all member banks to execute remittances electronically in the most expeditious manner. From the remitter/beneficiary perspective this would mean extremely quick turnaround times for foreign remittances and for banking intermediaries. This would allow more transactions to be executed with the same level of resources. In this manner the distinct advantages of processing transactions electronically would become palpably clear to processing personnel.

In Bangladesh nine banks are member of ELDORADO and at present only these banks can transfer funds within each other through ELDORADO. More banks will be members of this service and when all banks will be connected through ELDORADO network only then the true essence of online banking and EFT will be enjoyable. The current member banks are:

- Al-Arafah Islami Bank Limited

- Bank Asia Limited

- BRAC Bank Limited

- Dhaka Bank Limited

- EXIM Bank Limited

- Mutual Trust Bank Ltd.

- Social Islami Bank Ltd.

\section{Services Via ELDORADO}

1. Initiate local payment i.e. make a home currency payment to another bank account in the same country.

2. Initiate payment or schedule a payment on instruction basis

3. Payments are template driven and possible to store for future reference.

4. Customer details are populated from customer database maintained in the application.

5. Real-time status checking of payment instruction.

6. Put a payment on hold during initiation or at any stage of the approval cycle.

7. Configure payment requests for additional authentication by using transaction password.

\section{Conclusion}

In Bangladesh banks are still reluctant to use full internet base banking activities. Compared to private and foreign banks, nationalized commercial banks are far behind implementing internet banking system in banking transactions. Despite being a least developed country, selected segments of the Bangladeshi banking community has embraced technology with reasonable success. Personal computers and the internet are also emerging as day-to-day banking tools. These positive indicators are favoring the prospects of online banking in Bangladesh.

In the aspect of Bangladesh banking sector online banking system is one of the bless modernization. Most of our bank has not any marketing or sales forces to execute the raw and cold business of online banking for their own organization. In our country customers are not properly conscious about the advantage of the modern technology. Many multinational banks have already introduced new marketing activities to their targeted customers for specialized services which are found very effective. However, from last 10 years it has got tremendous importance over the bank customers and we hope it will increase day by day. Although online banking has a few risk in this field but it has much advantage than negative aspects. In Bangladesh, today 
Banking industry is much enrich and extent than earlier period, It is one of the most wonderful movement to our national economy. It has developed including online banking system in our banking sector. Online banking is one of the most demanded and latest technologies in banking sector. Synergy between telecommunications and information technology has the proven capability of monitoring and administering the real-time transactions. Therefore, liberalizing the telecom and IT sectors as well as reforming the financial sector is the preconditions of successfully implementing internet banking in Bangladesh. Creating awareness among the NCBs and local PCBs management regarding internet banking is also essential. The Government and the Central Bank can play an important role here. In order for E-banking to continue to grow, the security and the privacy aspects need to be improved. With the security and privacy issues resolved, the future of E-banking can be very prosperous. The future of electronic banking will be a system where users are able to interact with their banks "worry-free" and banks are operated under one common standard

\section{References}

[1]. Graham George, "World tries a new way to pay". Financial times, November 8, 1996.

[2]. Islam, Monirul, "Proposed ICT infrastructure for E-banking in Bangladesh", March 06, 2005.

[3]. Kamrul Hasan, "E-Banking in Bangladesh": The Future of Banking.

[4]. Khan, A.R, "Bank Management" 4th ed. Ruby Publications, 2007.

[5]. Mahmood Shah, Steve Clarke, "E-Banking Management: Issues, Solutions, and Strategies".

[6]. Md. Ibrahim Khalil, Iqbal Ahmad, and Md. Delwar Hossain Khan, "Internet Banking: Development and Prospects in Bangladesh".

[7]. Md. Moktar Ali, R. Ahmed, Arifur Rahman, Md. Moshiul Azam, "Electronic Banking in Bangladesh: Potential and Constraints".

[8]. Mohammad Mizanur Rahman, "E-Banking in Bangladesh: Some Policy Implications".

[9]. Mohammad Mizanur Rahman, "Innovative Technology and Bank Profitability: The Bangladesh Experience", Working Paper Series: WP 0803, Bangladesh Bank.

[10]. Mohammad Shamsuddoha, "Electronic Banking in Bangladesh".

[11]. Nirmal Chandra Bhakta, Md. Mostafizur Rahman Sarder, Md. Shahid Reza, "Online Banking: Bangladesh Perspectives".

[12]. Rahman, M. Present status of E-Banking in Bangladesh, Journal of the Institute of Bankers' Bangladesh, 2002.

[13]. Raihan A. Computerization and IT in the Banking Sector of Electronic Banking in Bangladesh: Potential and Constraints, 2001.

[14]. Ali Mohammad Mahboob, "Management Information Systems for today's banking business: Bangladesh Perspective" South Asian Journal of Management, India.

[15]. Basel Committee, "Electronic Money: Provider Issues and Regulatory Structure".

[16]. Bauer, Paul W., "Making payments in Cyberspace".

[17]. www.google.com, www. wikipedia.com 